\title{
Socioeconomic Analysis of Tribal Farmers in the Gumla District of Jharkhand from Existing Agroforestry Practices
}

\author{
Amar Kumar, R.B. Sah, Bijay Kumar Singh and P.R. Oraon* \\ Department of Silviculture and Agroforestry, Faculty of Forestry, Birsa Agricultural \\ University, Ranchi, Jharkhand, India \\ *Corresponding author
}

\begin{tabular}{|l|}
\hline Ke y w o r d s \\
Agroforestry, \\
Agrisilviculture, \\
Agrihorticulture, \\
Tribal, Socioeconomic \\
\hline Article Info \\
\hline $\begin{array}{l}\text { Accepted: } \\
\text { 04 May 2018 } \\
\text { Available Online: } \\
\text { 10 June 2018 }\end{array}$ \\
\hline
\end{tabular}

Agroforestry is a dynamic and sustainable land management system of deliberately growing woody perennials along with agricultural crops on farmlands to secure both tangible and intangible benefits to the farmers.It plays a vital role in conserving our natural resources, thus it is a step towards sustainable productivity. The present study is the outcome of socio-economic diagnosis of traditional agroforestry practices followed by farmers in Gumla district of Jharkhand. Among cast categories ST (92.50\%) was the most dominant caste followed by GEN $(5.00 \%)$ whereas minimum SC $(0.83 \%)$ in the study area. The existing agroforestry practices of households adopted i.e. agrisilviculture and agrihorticulture. Total annual income of household's 37.50 percent respondents earns upto Rs. 30,001 to 60,000 followed by 22.50 percent earn Rs. 60,001 to 90,000 , and minimum 6.67 percent earn more than Rs. 1, 20,000 per annum. In this area $70.00 \%$ of respondents had interested to grow forest trees on their own farm land whereas $95.00 \%$ of respondents had interested to grow horticulture trees on their own farm land whereas. Therefore traditional agroforestry systems also provides some assistance originating from traditional knowledge to the farmer and local communities in one or another way thereby ensuring livelihood options for the farmers of the district.

\section{Introduction}

Agroforestry can be defined as a dynamic, ecologically-based natural resources management system that through the integration of trees in agricultural landscapes diversifies and sustains production for increased social, economic and environmental benefits (Msuya and Kideghesho, 2012). Agroforestry system is also suitable for small holding to increase soil productivity and land sustainability. Thus agroforestry is a collective name for land use system and technology where woody perennials (tree, shrubs, palms, bamboo etc.) are deliberately used on same land management unit along with agricultural crops (Singh and Osman, 1987). Agroforestry, like multifunctional agriculture, has the objective of promoting economically, socially, and environmentally sustainable rural development (Leakey, 2012). It provides opportunities to increase the value of total production through marketing of multiple products from a given unit of land (Feldhake et al., 2008). Agroforestry, which is the inclusion of woody perennials in farming 
systems, has been practiced as traditional land use and livelihood option in Jharkhand state of India since time immemorial. The Jharkhand state is well known for its vast coal reserves and forest cover, which also includes the traditional agroforestry systems. The state is having 4.21 per cent of total geographical area under tree green cover in agroforestry (FSI, 2011). Among various states of Eastern India (Eastern Uttar Pradesh, Bihar, Jharkhand, Odisha, Chhattisgarh, West Bengal and Assam), Jharkhand has the highest area under wastelands/ degraded lands (14.84\%), followed by Assam (11.20\%) and Odisha (10.69\%) (World Bank, 2007). There is a need to restore those wastelands/degraded lands through agroforestry interventions in order to supply the increasing demands of food, fuel, fodder and timber requirements of rural folks in Jharkhand. Thus agroforestry serves as one of the option to tackle the problems of resource degradations and it's over exploitation in this state.

\section{Materials and Methods}

Gumla District is situated in the southwest portion of the Jharkhand state. It is lies between $22^{\circ} 35^{\prime \prime}$ to $23^{\circ} 33^{\prime \prime}$ North Latitude and $84^{\circ} 40^{\prime \prime}$ to $85^{\circ} 1^{\prime \prime}$ East Longitude. The average temperature is about $23^{\circ} \mathrm{C}$ and average annual rainfall in the district was 1400-1600 mm. Multi stage random sampling was adopted to select the households. Bishunpur block was selected randomly in the first stage. Two panchayats Banari and Chirodih were selected randomly for the study. A list of villages was prepared for each selected panchayat. Further, two villages Salam Nava Toli and Titahi from Banari panchayat and Deorangi and Champatoli from Chirodih panchayat was selected. Since data on number of households in each village were not available, a list of households in each of the selected villages was prepared by employing data collectors. From each village, thirty households were selected using simple random sampling. Thus, a total of 120 households were chosen for the purpose of this study. Each village was visited before administering the questionnaires. Interviews were conducted during the evenings (near dinner time) and early mornings, for farmers who were available only during these times. A response rate of $95 \%$ was obtained. Since data were not available on the number of households in each village, a list of households in each of the selected villages was prepared. The questionnaire was then finalized on the basis of validity, suggestions, corrections and comment of the research supervisor and experts. A few modifications and reduction in the number of questions were done taking cognizance of time constraints of the interview.

\section{Results and Discussion}

\section{Demographic details of the households}

The study indicated that Male headed families were found to be $90.00 \%$ and female headed families were found $10.00 \%$ in the Bishunpur Block. The age of the farmers ranged from 22 years to 72 years and majority of the farmers $(35.83 \%)$ were between 30 and 40 years. The further view on the data in table 1 showed that in Bishunpur Block $67.50 \%$ households were illiterate. In literate categories $13.33 \%$ households were educated at matric level and those were closely followed by $11.67 \%$ households study at elementary education. Highly educated viz., intermediate level household was only $4.17 \%$ and $3.33 \%$ at college level. Similar pattern in respect to literacy of households was observed in the sample surveyed. According to Boateng (2008) reported high level of literacy rate is likely to increase technical efficiency but decrease conservatism. Therefore, the findings of the present study indicate hindrance in adopting agroforestry but they can maintain or 
retain the existing trees on farms. Rahman et $a l$. , (2008) found that agroforestry and nonagroforestry farmers do not differ greatly in terms of general educational level in Litchi chinensis based agroforestry in North Bangladesh and concluded that lack of general education cannot explain the very low adoption rates of agroforestry. A further perusal of data indicated that all the cast categories were present in Bishunpur Block. Among these cast categories, ST (92.50\%) was the most dominant caste followed by GEN $(5.00 \%)$ whereas SC $(0.83 \%)$ was minimum.

Among villages, similar pattern was observed here also ST households were found dominant in all the villages whereas SC family was found to be the least dominant as only one SC family was found in the sample surveyed. In the study area 86.65 percent households reside in kuchcha house. The living standard of household depends largely on household's income. Majority of the households in the study area are unemployed and for their livelihood they depend on farming and that too on marginal and small farm holdings. Improvement in existing agroforestry practices can bring prosperity in their lives. A perusal of the table indicated that in the Bishunpur Block, nuclear family was found to be the highest family type (80.83\%) whereas joint family was the lowest family type (19.17\%). The majority of households were having family members five to seven $(47.50 \%)$ or up to four $(45.83 \%)$. Households having above eight family members were quite low $(6.67 \%)$ in the block.

A further view on the data in table showed that majority of households $(54.17 \%)$ was unemployed. Households with one employed person were 37.50 percent. Remaining households $(8.33 \%)$ were having with two employed persons (Glover et al., 2013; Himshikha, 2016; Thakur et al., 2018).

\section{Occupational profile of households}

The occupation profile of the household is divided into two groups i.e. primary and secondary. The primary occupation has been divided into three group, namely farming, government and business, Secondary occupation has been also divided into three group namely private job, agricultural labour and construction worker. The occupational profile of household i.e. primary and secondary occupation of the study areas is given in Table 2. A study indicated that in the almost all households (99.17\%) were engaged in farming. It is necessary to mention that no household was engaged in government job. In perusal of data it can be arrived that farming was the main occupation the households. A further study with respect to secondary occupation it is indicated that 38.33 percent households worked as agricultural labour and 26.67 percent households were engaged in construction works and only 14.17 percent were engaged in private job. The substantial additional income obtained from these activities could be used to finance farming activities. This is an incentive to agroforestry adoption and its subsequent impact on the living standards of rural farming households. According to Sood (2005) wealth status is one of the factors that cushion the risk of adoption of any innovation, and total household annual income is one of the indicators of wealth status of farmers. Higher household income is expected to increase the risk-bearing capacity of smallholder farmers' decision making and the willingness to wait for the returns from long term investment such as trees (Sood, 2006).

\section{Households' status of livestock}

The livestock and poultry are very important aspect for upliftment of livelihoods of the rural people. The livestock reared by farmers includes cow, buffalo, goats and poultry which 
are represented in Table 3. Perusal of data indicated that $87.50 \%$ respondents had cow followed by $85.83 \%$ had goats and poultry, and $05.83 \%$ respondents had buffalo. Among the livestock and poultry, the interest of possessing buffalo by respondents was very low. The animals contribute to the household in diverse ways. Animals provide source of food for the farmers and their household and are also reared for using in agriculture cultivation on own farm as well as to hire out for raising income.

\section{Number of households engaged in income generation from livestock}

The number of households engaged in income generation from livestock and poultry at household level are represented in Table 4. The study of respondents of selected villages indicated that $85.83 \%$ household rear goats. Similarly, $75.83 \%$ respondents were engaged in poultry, whereas $70.83 \%$ were engaged in dairy for their livelihood and income generation. Almost all respondents accepted that they engaged in more than one source of livelihood and income generation at household level. Livestock husbandry is a vital component of farming system in the study area.

It provides both goods and services in the form of food, dung and other products. A major output of cattle production that goes to farmland is dung as farmyard manure which contributes a major source for maintaining soil fertility in the study area. Buffaloes and cows are kept mainly for milk and manure production; oxen for draught power and manure; and goats for meat and cash income. Commonly, goats are grazed all-round the year. Cows and oxen are grazed all-round the year to fulfil the demand of animal feed. Cows, goats and oxen are generally grazed in forest and shrub land as well as on private land. Cows and oxen are stall-fed only during fallow and rain free period. Livestock husbandry practice of stall-feeding is achieved by providing grass, weed, and herbaceous fodder, tree leaf fodder collected from agricultural lands and community forests in the livestock sheds.

\section{Households' annual income}

The revenue generated from agriculture produce, horticulture produce, agro forestry produce and livestock by the respondents is shown in table 5. An examination of data of annual income from agriculture produce indicated that $55.83 \%$ of respondents had income group under Rs. 20,001-40,000 followed by $41.67 \%$ respondents had income upto Rs. 20,000 and $2.50 \%$ of respondents had income more than Rs. 40,000. It is quite interesting to note the primary occupation of the most of the respondents was agriculture but, only $2.50 \%$ respondents had annual income from agriculture above Rs. 40,000. Likewise, only $5.83 \%$ households earn money from agroforestry produce. Out of this, $3.33 \%$ respondents earn upto Rs. 5000, 1.67 percent respondents earn from Rs. 5,001 to 10,000 and only $0.83 \%$ earn above than Rs.10,000 per annum. Similarly, $67.67 \%$ households earn money from livestock component. Out of this, $29.17 \%$ respondents earn upto Rs. 15,001 to $25,000,19.17 \%$ earn upto Rs. 15,000 and only $18.33 \%$ earn more than Rs. 25,000 per annum. Likewise, in total annual household's income from farm practices $50.00 \%$ respondents earn upto Rs. 30,001 to 60,000 followed by $35.83 \%$ earn upto Rs. 30,000 and only $14.17 \%$ earn more than Rs. 60,000 per annum. It is established fact that households' income depends on farm size and components. If farm size and components increase then farmers' income also increases. Accordingly farmers can earn more money from selling diversified forest, agriculture and livestock products which leads to a sustainable life with high social status. 
Table.1 Demographic details of the households

\begin{tabular}{|c|c|c|c|}
\hline \multicolumn{2}{|l|}{ Details of the Household } & Total $(\mathrm{N}=120)$ & $(\%)$ \\
\hline \multirow[t]{2}{*}{ Gender } & Male & 108 & 90.00 \\
\hline & Female & 12 & 10.00 \\
\hline \multirow{5}{*}{ Age Profile } & $20-30$ & 15 & 12.50 \\
\hline & $30-40$ & 43 & 35.83 \\
\hline & $40-50$ & 21 & 17.50 \\
\hline & $50-60$ & 29 & 24.17 \\
\hline & Above 60 & 12 & 10.00 \\
\hline \multirow{5}{*}{ Literacy } & Illiterate & 81 & 67.50 \\
\hline & Elementry & 14 & 11.67 \\
\hline & Matric & 16 & 13.33 \\
\hline & Intermediate & 5 & 04.17 \\
\hline & College & 04 & 03.33 \\
\hline \multirow{4}{*}{ Caste } & GEN & 06 & 5.00 \\
\hline & $\mathrm{OBC}$ & 02 & 1.67 \\
\hline & $\mathrm{SC}$ & 01 & 0.83 \\
\hline & ST & 111 & 92.50 \\
\hline \multirow{3}{*}{ House Type } & Kuchcha & 104 & 86.65 \\
\hline & Mixed & 15 & 12.50 \\
\hline & Pucca & 01 & 00.83 \\
\hline \multirow[t]{2}{*}{ Type of Family } & Nuclear & 97 & 80.83 \\
\hline & Joint & 23 & 19.17 \\
\hline \multirow{3}{*}{$\begin{array}{l}\text { Total No. of Family } \\
\text { Member }\end{array}$} & Up to 4 & 55 & 45.83 \\
\hline & 5 to 7 & 57 & 47.50 \\
\hline & Above 8 & 08 & 6.67 \\
\hline \multirow{3}{*}{$\begin{array}{l}\text { No. of person } \\
\text { employed from family }\end{array}$} & 00 & 65 & 54.17 \\
\hline & 01 & 45 & 37.5 \\
\hline & 02 & 10 & 08.33 \\
\hline
\end{tabular}

Table.2 Occupational profile of households

\begin{tabular}{|l|l|c|c|}
\multicolumn{2}{|c|}{ Occupation } & $\begin{array}{l}\text { Total } \\
(\mathrm{N}=120)\end{array}$ & $(\%)$ \\
\hline \multirow{3}{*}{ Primary } & $\begin{array}{l}\text { Farming including } \\
\text { agroforestry }\end{array}$ & 118 & 99.17 \\
& $\begin{array}{l}\text { Government Job } \\
\text { Business }\end{array}$ & 00 & 00.00 \\
\hline \multirow{3}{*}{$\begin{array}{l}\text { Secondar } \\
\text { y }\end{array}$} & Private Job & $17 \#$ & 0.83 \\
\hline Agricultural Labour & $46 \#$ & 14.17 \\
\hline \# Multiple Answer & Construction Worker & $32 \#$ & 26.33 \\
\hline
\end{tabular}


Table.3 Households' status of livestock

\begin{tabular}{|l|c|c|}
\hline Livestock and poultry & Total $(\mathbf{N}=\mathbf{1 2 0})$ & $(\%)$ \\
\hline Cow & $105 \#$ & 87.50 \\
\hline Buffalo & $07 \#$ & 05.83 \\
\hline Goats & $103 \#$ & 85.83 \\
\hline Poultry & $103 \#$ & 85.83 \\
\hline \# Multiple answer & & \\
\hline
\end{tabular}

Table.4 Number of households engaged in income generation from livestock

\begin{tabular}{|l|c|c|}
\hline Source & Total $(\mathbf{N = 1 2 0})$ & $(\%)$ \\
\hline Dairy & $85 \#$ & 70.83 \\
\hline Goatery & $103 \#$ & 85.83 \\
\hline Poultry & $91 \#$ & 75.83 \\
\hline \# Multiple answer & &
\end{tabular}

Table.5 Households' annual income

\begin{tabular}{|c|c|c|c|}
\hline \multicolumn{2}{|l|}{ Farm practices } & Total $(\mathrm{N}=120)$ & $(\%)$ \\
\hline \multirow{3}{*}{$\begin{array}{l}\text { Agriculture } \\
\text { (Rs.) }\end{array}$} & Up to 20000 & 50 & 41.67 \\
\hline & 20001 to 40000 & 67 & 55.83 \\
\hline & Above 40000 & 03 & 2.50 \\
\hline \multirow{3}{*}{$\begin{array}{l}\text { Horticulture } \\
\text { Produce } \\
\text { (Rs.) }\end{array}$} & Up to 5000 & 01 & 0.83 \\
\hline & 5001 to 10000 & 06 & 5.00 \\
\hline & Above 10000 & 10 & 8.33 \\
\hline \multirow{3}{*}{$\begin{array}{l}\text { AF Produce } \\
\text { (Rs.) }\end{array}$} & Up to 5000 & 04 & 3.33 \\
\hline & 5001 to 10000 & 02 & 1.67 \\
\hline & Above 10000 & 01 & 0.83 \\
\hline \multirow{3}{*}{$\begin{array}{l}\text { Live-Stock } \\
\text { (Rs.) }\end{array}$} & Up to 15000 & 23 & 19.17 \\
\hline & 15001 to 25000 & 35 & 29.17 \\
\hline & Above 25000 & 22 & 18.33 \\
\hline \multirow{3}{*}{$\begin{array}{l}\text { Total } \\
\text { (Rs.) }\end{array}$} & Up to 30000 & 43 & 35.83 \\
\hline & 30001 to 60000 & 60 & 50.00 \\
\hline & Above 60000 & 17 & 14.17 \\
\hline \multicolumn{4}{|c|}{ Households' Off-farm income } \\
\hline \multirow{3}{*}{$\begin{array}{l}\text { Govt. Employee } \\
\text { (Rs.) }\end{array}$} & Up to 50000 & 00 & 0.00 \\
\hline & 50001 to 100000 & 00 & 0.00 \\
\hline & Above 100000 & 00 & 0.00 \\
\hline \multirow{2}{*}{$\begin{array}{l}\text { Private Job } \\
\text { (Rs.) }\end{array}$} & Upto 50000 & 07 & 5.83 \\
\hline & 50001 to 100000 & 08 & 6.67 \\
\hline \multirow{4}{*}{$\begin{array}{l}\text { Wages } \\
\text { (Rs.) }\end{array}$} & Up to 50000 & 30 & 25.00 \\
\hline & 50001 to 100000 & 04 & 3.33 \\
\hline & Up to 100000 & 01 & 0.83 \\
\hline & Above 100000 & 01 & 0.83 \\
\hline \multirow{3}{*}{$\begin{array}{l}\text { Total } \\
\text { (Rs.) }\end{array}$} & Up to 50000 & 38 & 31.67 \\
\hline & 50001 to 100000 & 12 & 10.00 \\
\hline & Above 100000 & 02 & 1.67 \\
\hline \multicolumn{4}{|c|}{ Households' total annual income } \\
\hline \multicolumn{2}{|l|}{ Up to 30000} & 25 & 20.83 \\
\hline \multicolumn{2}{|l|}{30001 to 60000} & 45 & 37.50 \\
\hline \multicolumn{2}{|l|}{60001 to 90000} & 27 & 22.50 \\
\hline \multicolumn{2}{|l|}{90001 to 120000} & 15 & 12.50 \\
\hline \multicolumn{2}{|l|}{ Above 120000} & 08 & 6.67 \\
\hline
\end{tabular}


Table.6 Tree species in agroforestry systems

\begin{tabular}{|l|l|l|} 
S1. No. & Agroforestry systems & \multicolumn{1}{|c|}{ Tree Species } \\
1. & $\begin{array}{l}\text { Agrisilviculture } \\
\text { system }\end{array}$ & $\begin{array}{l}\text { Acacia auriculiformis, Melia azadirachta, Bamboo spp., Gmelina } \\
\text { arborea, Madhuca indica, Moringa oleifera, Azadirachta indica, } \\
\text { Butea monosperma, Shorea robusta, Bombax ceiba, Dalbergia } \\
\text { sissoo, Tectona grandis and Laucaena leucocephala }\end{array}$ \\
\hline 2. & $\begin{array}{l}\text { Aiziphus mauritiana, Psidium guajava, Syzygium cumini, } \\
\text { Artocarpus heterophyllus, Diospyros melanoxylon, Litchi } \\
\text { shinensis, Carica papaya and Mangifera indica }\end{array}$
\end{tabular}

Table.7 Preference of forest trees and horticulture tree species

\begin{tabular}{|c|c|c|c|}
\hline Common name & \multicolumn{2}{|c|}{$\begin{array}{c}\text { Botanical Name } \\
\text { Fissoo }\end{array}$} & \multicolumn{2}{|c|}{ Total Point } & $(\%)$ \\
\hline Gamhar & Dalbergia sissoo & 292 & 26.24 \\
\hline Teak & Gmelina arborea & 253 & 22.73 \\
\hline Akashi & Tectona grandis & 221 & 19.86 \\
\hline Subabool & Acacia auriculiformis & 128 & 11.50 \\
\hline Moringa & Laucaena leucocephala & 087 & 7.82 \\
\hline Mahua & Moringa oleifera & 069 & 5.20 \\
\hline & Madhuca indica & 063 & 34.66 \\
\hline Mango & Hangifera indica & & 23.33 \\
\hline Guava & Psidium guajava & 560 & 13.52 \\
\hline Banana & Musa paradisiaca & 383 & 9.08 \\
\hline Kathal & Artocarpus heterophyllus & 222 & 8.65 \\
\hline Litchi & Litchi chinensis & 149 & 6.03 \\
\hline Papaya & Carica papaya & 142 & 5.30 \\
\hline Ber & Ziziphus mauritiana & 099 & 087 \\
\hline
\end{tabular}

Table.8 Respondents' willingness to grow forest trees and horticulture trees species on their farm in future

\begin{tabular}{|c|c|c|c|c|c|}
\hline \multirow[t]{2}{*}{ Forest Trees } & \multicolumn{5}{|c|}{ Household No. (\%) } \\
\hline & $\begin{array}{c}\text { Salam Nava Toli } \\
\qquad(\mathrm{n}=\mathbf{3 0})\end{array}$ & $\begin{array}{l}\text { Titahi } \\
(\mathbf{n}=30)\end{array}$ & $\begin{array}{c}\text { Deorangi } \\
(\mathbf{n}=\mathbf{3 0})\end{array}$ & $\begin{array}{c}\text { Champa Toli } \\
(\mathbf{n}=\mathbf{3 0})\end{array}$ & $\begin{array}{c}\text { Total } \\
(\mathbf{N}=\mathbf{1 2 0})\end{array}$ \\
\hline Yes & $\begin{array}{c}23 \\
(76.67)\end{array}$ & $\begin{array}{c}24 \\
(80.00)\end{array}$ & $\begin{array}{c}20 \\
(66.67)\end{array}$ & $\begin{array}{c}17 \\
(56.67)\end{array}$ & $\begin{array}{c}84 \\
(70.00))\end{array}$ \\
\hline No & $\begin{array}{c}07 \\
(23.33)\end{array}$ & $\begin{array}{c}06 \\
(20.00)\end{array}$ & $\begin{array}{c}10 \\
(33.33)\end{array}$ & $\begin{array}{c}13 \\
(43.33)\end{array}$ & $\begin{array}{c}36 \\
(30.00)\end{array}$ \\
\hline \multicolumn{6}{|c|}{ Horticulture trees } \\
\hline Yes & $\begin{array}{c}28 \\
(93.33)\end{array}$ & $\begin{array}{c}29 \\
(96.67)\end{array}$ & $\begin{array}{c}29 \\
(96.67)\end{array}$ & $\begin{array}{c}28 \\
(93.33)\end{array}$ & $\begin{array}{c}114 \\
(95.00)\end{array}$ \\
\hline No & $\begin{array}{c}02 \\
(06.67)\end{array}$ & $\begin{array}{c}01 \\
(03.33)\end{array}$ & $\begin{array}{c}01 \\
(03.33)\end{array}$ & $\begin{array}{c}02 \\
(06.67)\end{array}$ & $\begin{array}{c}06 \\
(05.00)\end{array}$ \\
\hline
\end{tabular}


Similarly, literature also finds that farm size is significantly positively related to farmers' income (Safa, 2005; Chakraborty et al., 2015).

Total annual household's income $37.50 \%$ respondents earn upto Rs. 30,001 to 60,000 followed by $22.50 \%$ earn Rs. 60,001 to 90,000 and only 6.67 percent earn more than Rs. 1, 20,000 per annum.

Similarly McGinty et al., (2006) observed that average annual income of farmers significantly contributes to farmers' intentions to adopt or maintain agroforestry.

\section{Tree species in different agroforestry system}

Tree species is found in different agroforestry system is shown in table 6 . The data indicated that tree species found in agrisilviculture system Acacia auriculiformis, Melia azadirachta, Bamboo spp., Gmelina arborea, Madhuca indica, Moringa oleifera, Azadirachta indica, Butea monosperma, Shorea robusta, Bombax ceiba, Dalbergia sissoo, Tectona grandis and Laucaena leucocephala where as in agrihorticulture system Ziziphus mauritiana, Psidium guajava, Syzygium cumini, Artocarpus heterophyllus, Diospyros melanoxylon, Litchi chinensis, Carica papaya and Mangifera indica. Similar findings observed in different districts of Jharkhand (Oraon et al., 2005, Hemrom and Nema 2015, Singh et al., 2017, Singh and Oraon 2017, Lakra et al., 2018).

\section{Preference of forest trees and horticulture tree species}

For first $1^{\text {st }}$ preference five points was given, for 2 nd four points, for $3^{\text {rd }}$ three points and likewise for 4th two points and for 5th one point was given to the preferred species. After calculating the willingness points of prefer horticulture tree species on their own farm land, the preference of horticulture tree species were found. The preferred forest trees are Madhuca indica, Gmelina arborea, Tectona grandis, Acacia auriculiformis, Laucaena leucocephala, Moringa oleifera and Dalbergia sissoo. The data indicated that Dalbergia sissoo (26.24 \%) was the first preference by the respondents followed by Gmelina arborea (22.73\%), Tectona grandis (19.86\%), Acacia auriculiformis (11.50\%), Leucaena leucocephala (7.82 \%).

Whereas, horticultural species the preference given by the respondents like Carica papaya, Litchi chinensis, Artocarpus heterophyllus, Ziziphus mauritiana, Musa paradisiacal, Psidium guajava and Mangifera indica. The data indicated that mango $(34.11 \%)$ was the first preference of the respondents followed by Guava (23.33 \%), Banana (13.52 \%), Kathal $(9.08 \%)$ and Litchi $(8.65 \%)$. Jamil (2003) reported that the farmers highly preferred Dalbergia sissoo and Acacia nilotica for planting on their farms on account of better economic value, quality timber, fuel wood and fodder (Table 7).

Hemrom and Nema (2015) found similary in Agrisilvicuture system the combinations of trees like Shorea robusta, Tectona grandis, Acacia spp, Phoenix sylvestris etc and in horticultural species like in agri-hortisilviculture system the fruit trees Cocos nucifera, Caraya papaya, Musa acuminate, Mangifera indica, Anacardium ocidentale,Embellica officinalis. The tree species were Artocarpus heterophyllus, Azadirachta indica, Dalbergia sissoo, Gmelina arborea, Leucaena leucocephala, Melia azadarech, Syzygium cumini and Tectona grandis and in horticultural tree are Artocarpus heterophyllus, Litchi chinensis, Mangifera indica and Syzygium cumini (Oraon et al., 2005, Singh et al., 2017, Singh and Oraon 2017, Lakra et al., 2018). 
Respondents' willingness to grow forest trees and horticulture trees species on their farm in future

The willingness to grow forest trees and horticulture trees on farm land is shown in the table 8. Data indicated that $70.00 \%$ of respondents had interested to grow forest trees on their own farm land whereas $30.00 \%$ of the respondents had not agree to grow forest trees on their farm due to shortage of land and also shading effects on field crops. Whereas $95.00 \%$ of respondents had interested to grow horticulture trees on their own farm land whereas $5.00 \%$ of the respondents had not agreed to grow horticulture trees on their farm land.

Farmers in the study area are having sufficient farming experience, but few farmers are having adequate knowledge in agroforestry. The contribution of the trees in the farming systems certainly added to the diversity dimension by way of income and employment to the farm households besides fulfilling the requirement of wood. Income of households from the sale of agroforestry produce contributes only 2.41 percent to total annual income which indicative of enormous potential of improvement in existing agroforestry practices prevalent in the study area.

Therefore, social and economic conditions of the farmers should be taken into account to design for adoption of agroforestry by the farmers. Further, the traditional form of agroforestry plays a specific role in the livelihood and income generation of households and this should also be kept in mind while formulating an appropriate agroforestry system for farmers. Hence, planned expansion of agroforestry including improvement in existing agroforestry practices is advocated for overall socioeconomic development of the farmers.

\section{References}

Boateng, I. (2008). The impact of agroforestry on the livelihood of rural farming households: a case study of selected communities of Offinso, Afigya Sekyere and Atwima district. M.Sc. Agroforestry Thesis, Kwame Nkrumah University of Science and Technology, Kumasi, Ghana, $157+$ XIII 1

Chakraborty, M., Haider, M.Z. and Rahaman, M.M. (2015). Socio-Economic Impact of Cropland Agroforestry: Evidence from Jessore District of Bangladesh, International Journal of Research in Agriculture and Forestry, 2(1): 11-20.

Feldhake, C.M., Belesky, D.P. and Mathias, E.L. (2008). Forage Production Under and Adjacent to Robinia pseudoacacia in Central Appalachia, West Virginia. Advances in Agroforestry, 4: 55-66.

FSI (2011). India State of Forest Report, Forest Survey of India, Govt. of India, Dehradun, India.

Glover, E.K., Ahmed, H.B, Glover M. K. (2013). Analysis of socioeconomic conditions influencing adoption of agroforestry ractices. International Journal of Agriculture and Forestry, 3(4):178-184.

Hemrom, A. and Nema, S. (2015). A study on traditional agroforestry practices existing at Bastar region of Chhattisgarh. International Journal of Multidisciplinary Research and Development, 2(3):56-64.

Himshikha (2016). Assessment of socioeconomic status of agroforestry farmers in Haridwar, Uttarakhand. International Journal of Farm Sciences. 2016; 6(4):87-94

Jamil, M. (2003). Farmers Attitude Towards Tree Plantation in District Attock, M.Sc. (Hons.). Thesis, Pakistan Forest Institute, Peshawar.

Lakra, T, S., Siddiqui, M.H., Chakraborty, A.K., Oraon, P.R. and Malik, M. S. (2018). Agroforestry Practices Feollowed 
in West Singhbhum District, Jharkhand.

Trends in Biosciences, 11(4): pp 400-406

Leakey, R.B. (2012). Multifunctional Agriculture and Opportunities for Agroforestry: Implications of IAASTD. Advances in Agroforestry 9, 203-214.

McGinty M.M., Swisher M.E., and Alavalapati J. (2006). Agroforestry adoption and maintenance: self-efficacy, attitudes and socio-economic factors. Agroforestry Systems, 73: 99-108.

Msuya T. S. and Kideghesho J. R. (2012). Mmainstreaming agroforestry policy in Tanzania legal framework. In: Agroforestry for biodiversity and ecosystem services- science and practice (ML Kaonga ed), In Tech Publishers, DOI: $10.5772 / 35859$.

Oraon. P. R., Yadav, M. S. and Siddiqui, M. H. (2005). Comparative performance of Agroforestry in Kumharia Village of Ranchi District. Indian Journal of Agroforestry. Vol. 7 No. 2: pp 19 -24

Rahman, S. A., de Groot, W. T. and Snelder, D. J. (2008). Exploring the Agroforestry Adoption Gap: Financial and Socioeconomics of Litchi-Based Agroforestry by Smallholders in Rajshahi (Bangladesh). In: Nair, P.K.R., Snelder, D.J. and Lasco, R.D. (eds), Smallholder Tree Growing for Rural Development and Environmental Services: lessons from Asia (Advances in Agroforestry, Vol. 5), Springer Science, Leiden, The Netherlands, pp 227-244

Safa, M. S. (2005). Socio-Economic Factors Affecting the Income of Small-scale Agroforestry Farms in Hill Country Areas in Yemen: A Comparison of OLS and WLS Determinants, Small-scale Forest
Economics, Management and Policy, 4(1): 117-134.

Singh B. K. and Oraon P. R. (2017). Growth and Yield of Trees and Intercrops under Different Agroforestry System in Lohardga District of Jharkhand, Bull. Env. Pharmacol. Life Sci., Vol 6 [12] November: 53-58

Singh, B. K., Oraon, P. R., Kumar, A. and Malik M. S. (2017). Traditional Agroforestry practices existing at Lohardaga District of Jharkhand. Trends in Bioscience.10 (23): 4651-4654.

Singh, R.P. and Osman, M. Mohomad. (1987). Agroforestry system for small holdings. International Workershop on Agroforestry for Rural Needs, Vigyan Bhawan, New Delhi, February, 22-26.

Sood K.K. (2006). The influence of household economics and farming aspects on adoption of traditional agroforestry in Western Himalaya. Mountain Research and Development, 26(2):124-130.

Sood, K.K., Najiar, C. and Singh, K.A. (2005). Household level domestic fuel consumption, need hypothesis and agroforestry adoption: Lessons from Eastern Himalaya. Indian $J$. of Agroforestry, 35 (2):67-72

Thakur, P. K., Malik, M.S., Singh, B. K. and Oraon, P.R. (2018). Assessment of socioeconomic status of agroforestry farmers in Giridih District, Jharkhand, Journal of Pharmacognosy and Phytochemistry; SP1: 929-932

World Bank (2007). Jharkhand - Addressing the Challenges of Inclusive Development. Report No. 36437-IN, p.148.

\section{How to cite this article:}

Amar Kumar, R.B. Sah, Bijay Kumar Singh and Oraon, P.R. 2018. Socioeconomic Analysis of Tribal Farmers in the Gumla District of Jharkhand from Existing Agroforestry Practices. Int.J.Curr.Microbiol.App.Sci. 7(06): 595-604. doi: https://doi.org/10.20546/ijcmas.2018.706.068 